\title{
Scanning electron microscopic observation of Acarothrix grandocularis (Acari, Halacaridae) and notes on the species of the genus Acarothrix
}

\author{
TAPAS CHATTERJEE \\ Crescent International School, Bario, Govindpur, Dhanbad 828109, Jharkhand, India \\ Corresponding author, e-mail: drtchatterjee@yahoo.co.in
}

Keywords Acarothrix grandocularis, SEM, Distribution

Abstract Scanning electron microscopic observations of some characters of Acarothrix grandocularis Chatterjee, Marshall, Guru, Ingole, Pešić 2012 is presented. Distribution and characters of species belonging to the genus Acarothrix are also discussed.

Cechy Acarothrix grandocularis (Acari, Halacaridae) widoczne dzięki zastosowaniu mikroskopu skaningowego na tle rodzaju Acarothrix

Słowa kluczowe Acarothrix grandocularis, SEM, rozmieszczenie

Streszczenie Artykuł prezentuje cechy Acarothrix grandocularis Chatterjee, Marshall, Guru, Ingole, Pešić 2012 - widoczne dzięki zastosowaniu mikroskopu skaningowego. Dyskutowane są również cechy i rozmieszczenie gatunków należących do rodzaju Acarothrix.

\section{Introduction}

Acarothrix grandocularis Chatterjee, Marshall, Guru, Ingole and Pešić (2012) was first described from India and Brunei Darussalam among algal turf growing on pneumatophores of mangroves in estuarine habitats (Chatterjee et al., 2012). Bartsch (2015) reported this species from Kranji, Singapore among green and red algae on trunks of mangrove trees. In the present paper some morphological characters of $A$. grandocularis is studied in detail, based on scanning electron microscopic observation of specimens from Goa, India. Distribution and characters of species belonging to the genus Acarothrix are also provided. 


\section{Material and Methods}

Specimens were collected from Chorao Island (North Goa), Virnoda Pernem (North Goa), Chicalim Vasco (South Goa) and Chinchinim (South Goa) among algal turf growing on pneumatophores of mangroves or in mud flat associated with mangroves.

Specimens for scanning electron microscopy (SEM) were prefixed overnight at $4^{\circ} \mathrm{C}$ in $2.5 \%$ glutaraldehyde, followed by post fixation in $2 \%$ cold osmium tetroxide. After dehydration through a graded series of ethanol (50-100\% at 10\% interval) for 30 minutes each, the material was critical-point dried, and coated with a platinum-palladium mix in a high evaporator, and then examined with a scanning electron microscope.

The following abbreviations are used in the text and figure legends: AD, anterior dorsal plate; AE, anterior epimeral plate; ds1-5, dorsal setae 1-5 on the idiosoma; GA, genitoanal plate; GO, genital opening; OC, ocular plate(s); PAS, parambulacral seta(e); PD, posterior dorsal plate; PGS, perigenital setae; P1-4, first to fourth palpal segment; SGS, subgenital setae.

Study area: Chorao Island (North Goa), west coast of India: Latitude $15^{\circ} 30^{\prime} 45.74^{\prime \prime} \mathrm{N}$, Longitude $73^{\circ} 52^{\prime} 11.25^{\prime \prime} \mathrm{E}$. The Chorao Island is situated $5 \mathrm{kms}$ from Panaji. Island present in Mandovi river, water is brackish in nature and salinity from 3-7\%. Samples collected from algal turf associated with pneumatophores of Avicennia sp, Rhizophora sp.

Chicalim Vasco (South Goa), west coast of India: Latitude $15^{\circ} 24^{\prime} 20.49^{\prime \prime}$ N, Longitude $73^{\circ}$ 53' 18.97" E. Samples collected from algal turf associated with pneumatophores of Avicennia and Rhizophora sp. Samples also collected from mud flat associated with mangroves.

Virnoda Pernem (North Goa), west coast of India: Latitude $15^{\circ} 40^{\prime} 13.85^{\prime \prime}$ N, Longitude $73^{\circ}$ 43' 22.19". Samples collected from algal turf associated with pneumatophores of Rhizophora sp.

Chinchinim (South Goa), west coast of India: Chinchinim is located between Lat: $15^{\circ} 12^{\prime} \mathrm{N}$. Long: $73^{\circ} 58^{\prime} \mathrm{E}$ and $15.20^{\circ} \mathrm{N} 73.97^{\circ} \mathrm{E}$. Samples collected from mud flat in mangrove area. Avicennia sp dominated.

\section{Results and Discussion}

\section{Acarothrix grandocularis Chatterjee et al. 2012}

Acarothrix grandocularis Chatterjee et al. (2012, pp. 542-546, figs. 1A-D, 2A-F, 3A-D); Bartsch (2015, 100-102, figs. 2H-O).

Description: The original description of this species is given in Chatterjee et al. (2012) based on the specimens collected from Goa, India and Brunei Darussalam. Some characters referred in that paper are described in more details according to present SEM study based on the specimens collected from Goa, India.

$\mathrm{AD}, \mathrm{OC}$ and $\mathrm{PD}$ are separate (Figure 1A). Areolae and costae on dorsal plates slightly raised with porose panel (Figures 1F, 2A); remainder of plates panelled (2B). AD with one anterior and two posterior areolae; $1^{\text {st }}$ pair of gland pores inserted near anterolateral edge of posterior areolae; posterior margin of AD triangular. OC elongate, setae $\mathrm{ds}_{2}$ on $\mathrm{OC}$ (Figure 1D, E). PD with a pair of longitudinal porose costae, 2 porose panels wide (Figures 1F, 2A); setae $\mathrm{ds}_{3}-\mathrm{ds}_{5}$ on PD (2C, D). AE, PE and GA separate (Figure 1B, C). AE almost smooth (Figure 2E) with 3 pairs of ventral setae and a pair of epimeral pores, epimeral pore shown in Figure 2F. Three pairs of PGS present. Pair of SGS located at the anterior end of genital sclerites (Figure 3A). 

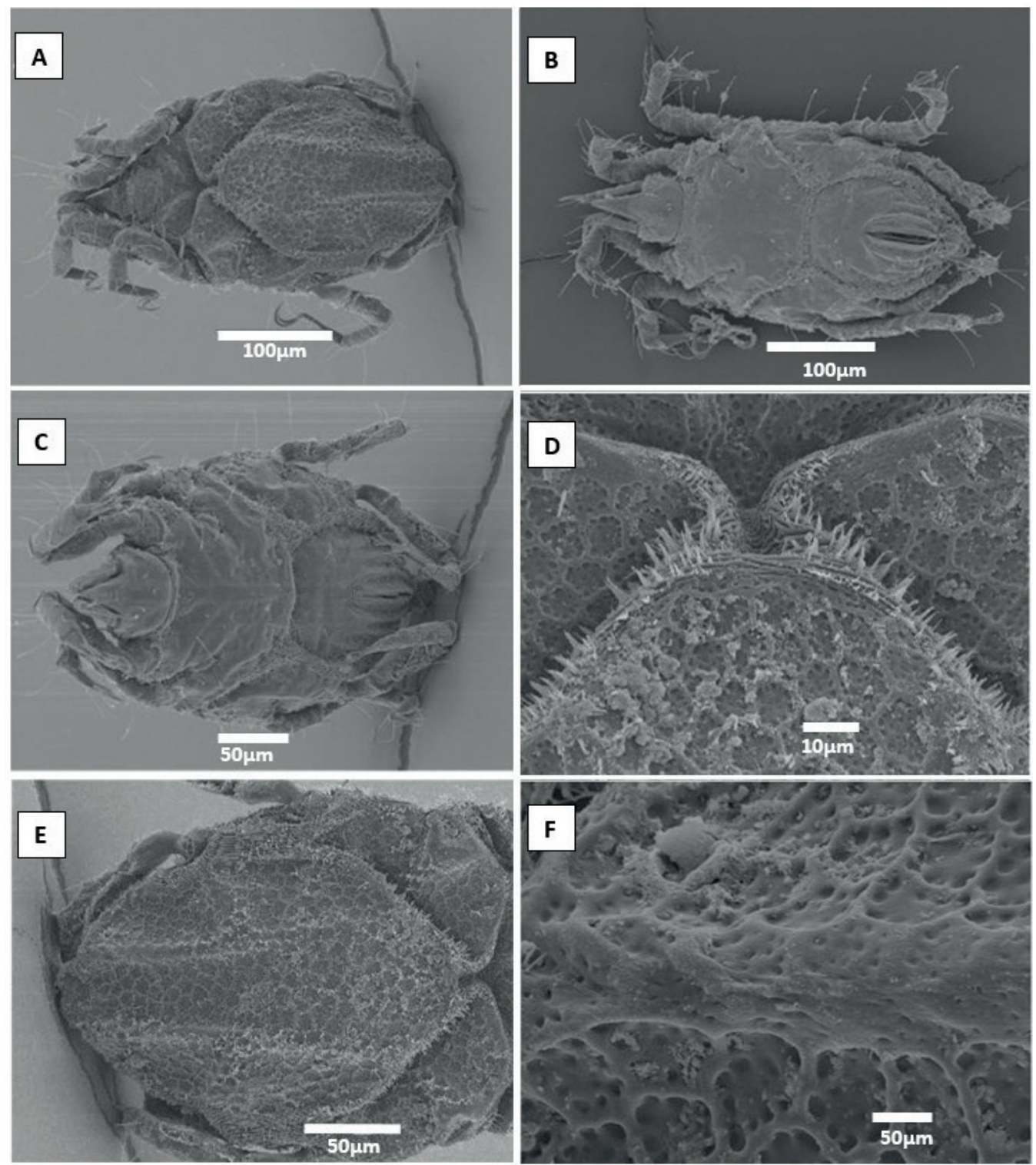

Figure 1. Acarothrix grandocularis Chatterjee et al. 2012, SEM figures, female. A. Idiosoma dorsal; B, C. Idiosoma ventral; D. Magnified view of parts of AD, OC and PD; E. OC and PD; F. Part of costa and panels on PD. 

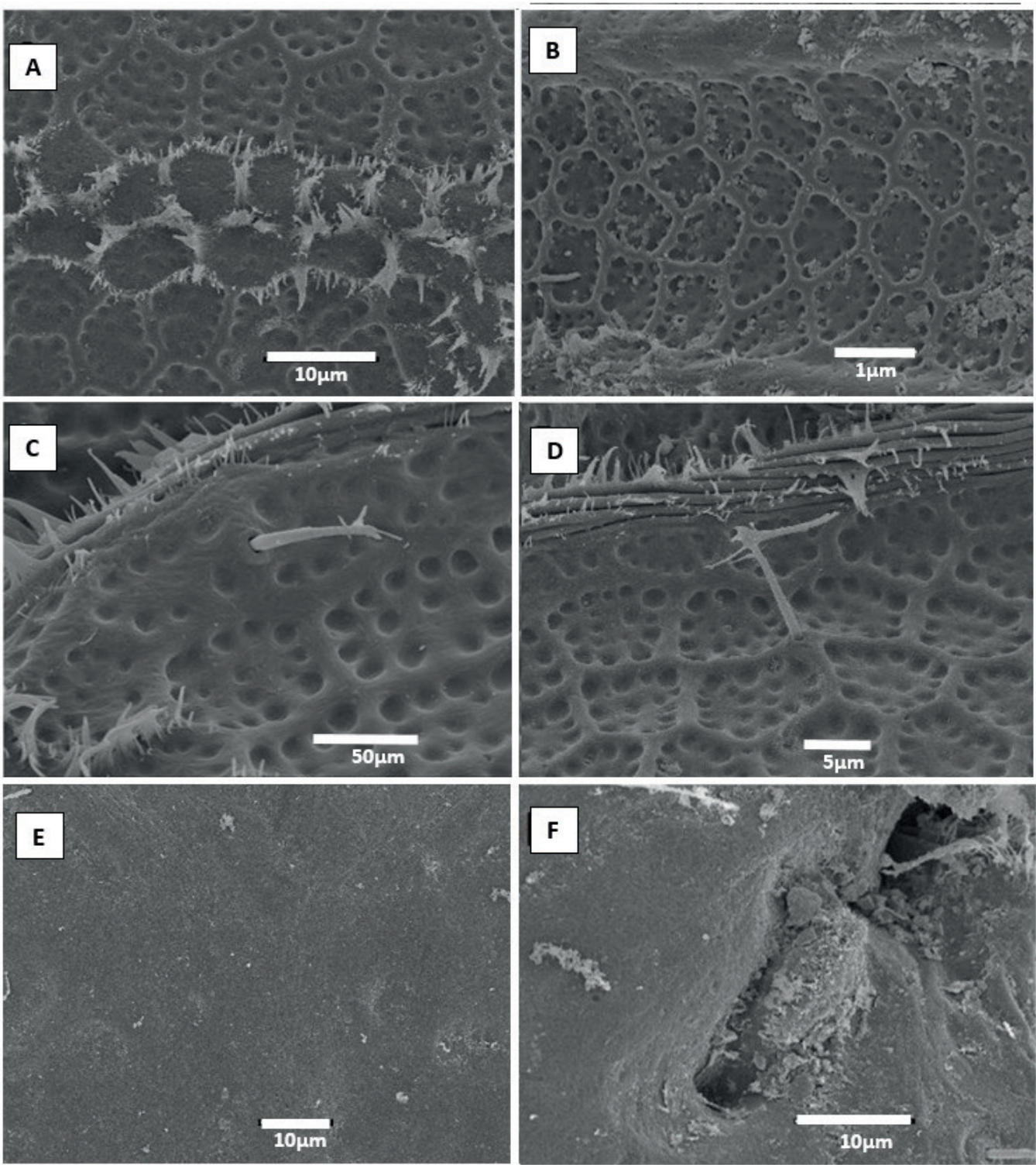

Figure 2. Acarothrix grandocularis Chatterjee et al. 2012, SEM figures, female. A. Part of costa on PD; B. Panels between two costae on PD; C. seta ds3 on PD; D. Seta ds4 on PD; E. Part of AE; F. Epimeral pore on AE. 


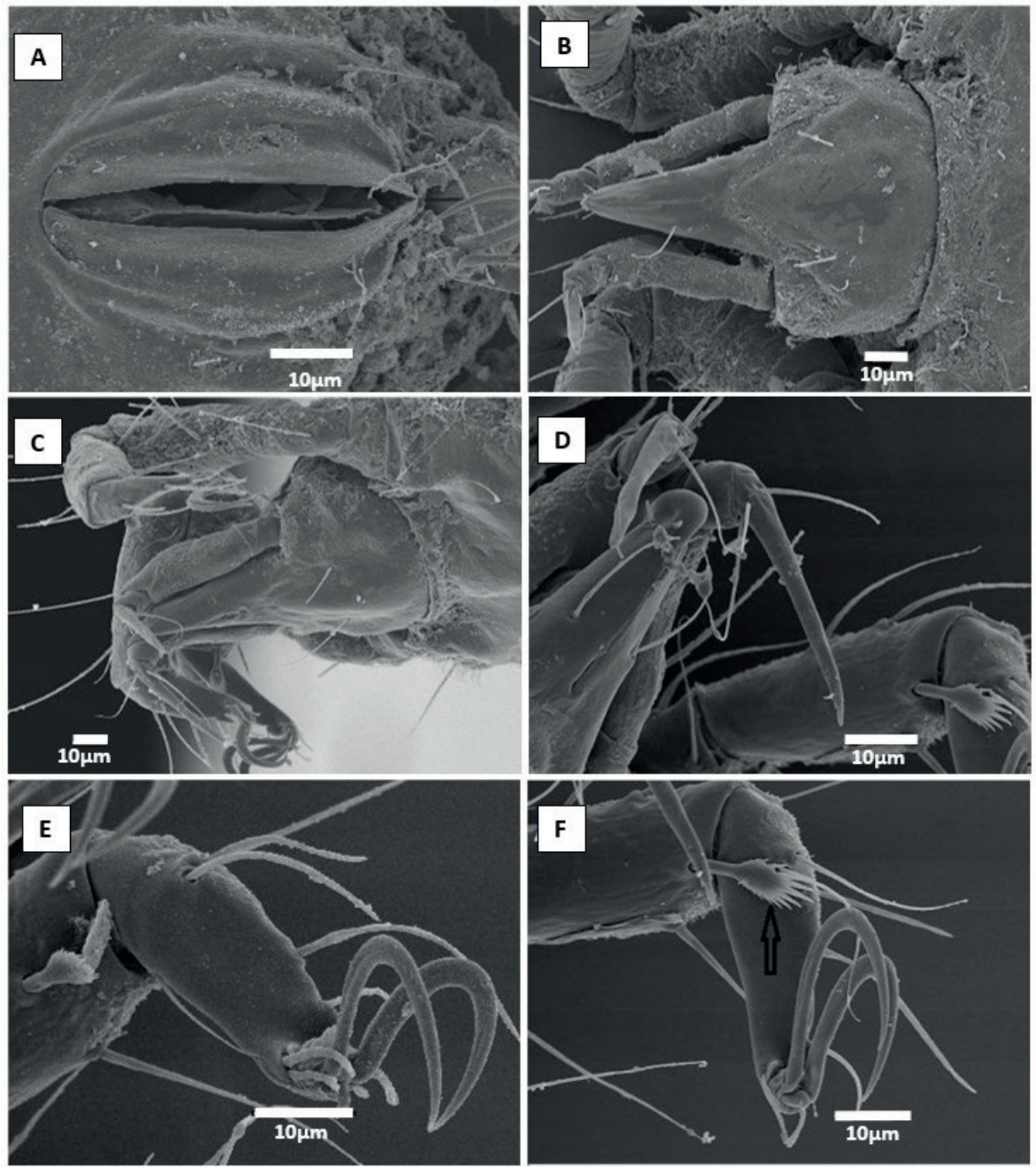

Figure 3. Acarothrix grandocularis Chatterjee et al. 2012, SEM figures, female. A. GO of female; B. Gnathosoma ventral view; C. Gnathosoma ventrolateral view; D. Anterior part of gnathosoma and palp; E. Part of tibia I and tarsus I; F. Part of tibia II and tarsus II (arrow indicating pectinate seta on tibia). 

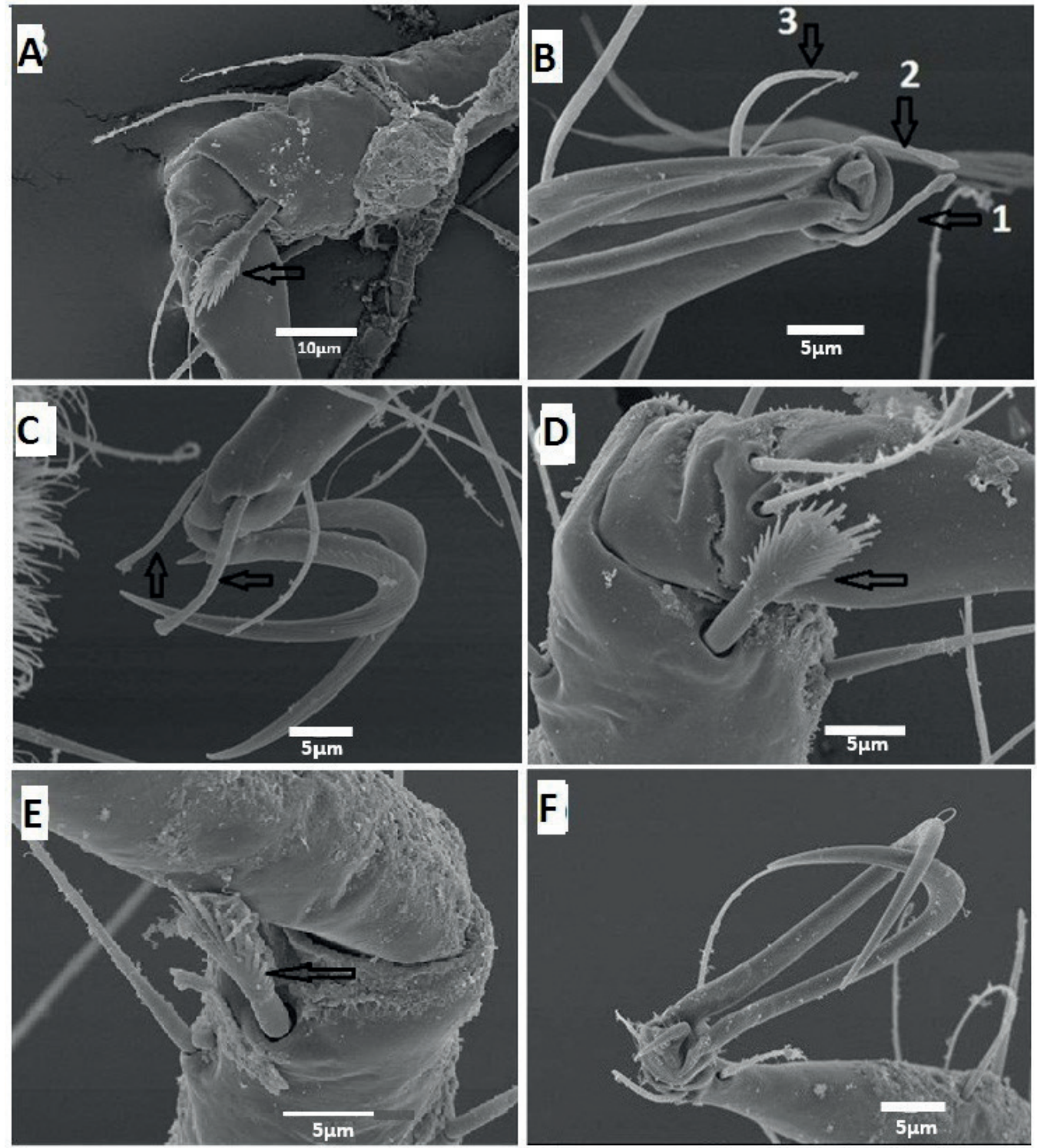

Figure 4. Acarothrix grandocularis Chatterjee et al. 2012, SEM figures, female. A, Part of tibia II and tarsus II (arrow indicating pectinate seta on tibia); B. Anterior part of tarsus II (arrow indicating 1., 2: PAS; 3: solenidion); C. Anterior part of tarsus II (arrow indicating PAS); D, E. Part of tibia and tarsus III (arrow indicating pectinate seta on tibia); D. Tip of tarsus III. 
Rostrum triangular, tip of rostrum not surpassing the anterior end of $\mathrm{P}_{2} . \mathrm{P}_{1}$ and $\mathrm{P}_{3}$ without any setae; $\mathrm{P}_{2}$ with 1 dorsal seta; $\mathrm{P}_{4}$ with 3 long proximal setae and 1 minute distal seta. Proto and deuto- rostral setae situated at the tip of rostrum, long maxillary setae of rostrum anterior to middle of rostrum, gnathosomal base with a pair of setae $(3 \mathrm{~B}, \mathrm{C})$. Rostral sulcus is extending posteriorly to just beyond the tritorostral setae (Figure 3B, D).

Tibiae I-IV with 1-1-1-0 bipectinate ventromedial setae. Pectinate seta shown in figures 3E, F, 4A, D, E. Tarsus I with 3 dorsal setae, 1 solenidion, 2 ventral setae, 2 doublet eupathid PAS (Figure 3E). Tarsus II with 3 dorsal setae, 1 solenidion, 2 single eupathid PAS (4B, C). Tarsus III with 4 dorsal setae and 2 PAS (4F). All tarsi with 2 lateral claws, a small bidentate medial claw, and a carpite; lateral claws smooth ventrally.

Remarks. In India. A. granocularis is found from both pneumatophores turf and mud flat also. The salinity of mangrove area ranges from 3-7\% . A detailed study based on SEM and molecular analysis for specimens from different localities is necessary to reveal variations in this species between the localities.

\section{Notes on species of the genus Acarothrix}

Acarothrix is a genus of halacarid mites that was proposed by Bartsch (1990) and has A. palustris Bartsch 1990 as the type species. There are five species viz. A. palustris Bartsch (1990), A. longiunguis Bartsch (1997), A. umgenica Procheş (2002), A. ampliata Bartsch (2004) and $A$. grandocularis Chatterjee et al. (2012) so far recorded under this genus.

The genus has been recorded from Southern China, Singapore, northern Australia, southeastern Africa, Florida and India. All species are known from tropical or warm temperate regions. Table 1 shows detail distribution of the species in Acarothrix along with the habitats and references.

Table 1. Species of Acrothrix: Localities with habitats

\begin{tabular}{|c|c|c|c|c|}
\hline Name of the species & Locality & Oceanic provinces & Habitat & References \\
\hline 1 & 2 & 3 & 4 & 5 \\
\hline $\begin{array}{l}\text { Acarothrix } \\
\text { ampliata } \\
\text { Bartsch } \\
2004\end{array}$ & $\begin{array}{l}\text { USA: Gulf of Mexico } \\
\text { at Tampa Bay, Florida }\end{array}$ & $\begin{array}{l}\text { ATW: Atlantic Ocean, } \\
\text { tropical west }\end{array}$ & $\begin{array}{l}\text { Little Manatee River, } \\
\text { which empties into } \\
\text { Tampa Bay }\end{array}$ & Bartsch (2004) \\
\hline \multirow[t]{2}{*}{$\begin{array}{l}\text { Acarothrix } \\
\text { ampliumeris } \\
\text { Bartsch } 2006\end{array}$} & Singapore & $\begin{array}{l}\text { PTW: Pacific Ocean, } \\
\text { tropical west }\end{array}$ & $\begin{array}{l}\text { Cladophora mat, } \\
\text { Chlorophyta, on } \\
\text { muddy and sandy } \\
\text { sediments in } \\
\text { mangrove area }\end{array}$ & Bartsch (2006) \\
\hline & $\begin{array}{l}\text { Singapore: End of Lim } \\
\text { Chu Kang Road }\end{array}$ & $\begin{array}{l}\text { PTW: Pacific Ocean, } \\
\text { tropical west }\end{array}$ & $\begin{array}{l}\text { Among green } \\
\text { (Cladophorales) and } \\
\text { red algae (Catenella } \\
\text { sp., Gigartinales) } \\
\text { on pneumatophores } \\
\text { of Avicennia } \text { sp. } \\
\text { (Avicenniaceae) } \\
\text { mangroves }\end{array}$ & Bartsch (2015) \\
\hline
\end{tabular}




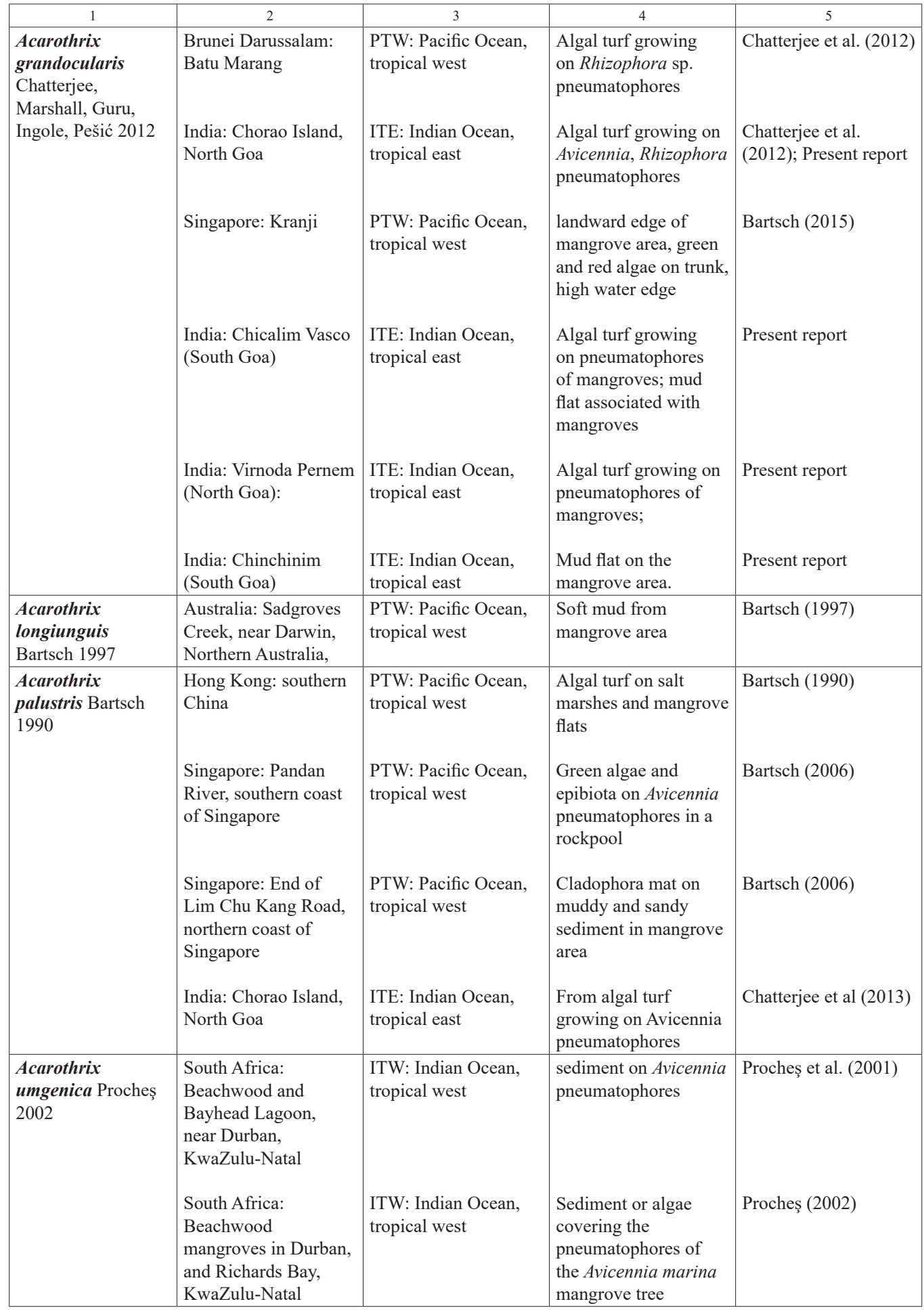


All species live in intertidal muddy environments characterized by fluctuating salinities. Four species of Acarothrix are found to be associated with mangroves (Chatterjee, Pfingstl, Pešić, 2018a).

Sexual dimorphism is common in many groups of Arthropoda. Sexual dimorphism is also found in some species of halacarid mites (Chatterjee, Guru, 2012). A pair of external genital acetabula is present on genital sclerites in males of the genus Acarothrix, while the external genital acetabula on genital sclerites are absent in the female.

A comparison of important characteristics between species in the genus Acrothrix is compiled in Table 2 .

Table 2. Comparison of important characteristics between species in the genus Acarothrix

\begin{tabular}{|c|c|c|c|c|c|c|}
\hline Characters & $\begin{array}{l}\text { Acarothrix } \\
\text { ampliata }\end{array}$ & $\begin{array}{c}\text { Acarothrix } \\
\text { ampliumeris }\end{array}$ & $\begin{array}{c}\text { Acarothrix } \\
\text { grandocularis }\end{array}$ & $\begin{array}{l}\text { Acarothrix } \\
\text { longiunguis }\end{array}$ & $\begin{array}{l}\text { Acarothrix } \\
\text { palustris }\end{array}$ & $\begin{array}{c}\text { Acarothrix } \\
\text { umgenica }\end{array}$ \\
\hline $\begin{array}{l}\text { Idiosoma } \\
\text { length }\end{array}$ & $\begin{array}{c}\text { Male } 326-340 \\
\text { Female } 340\end{array}$ & $\begin{array}{c}\text { Male } 314-325 \\
\text { Female } 294- \\
309\end{array}$ & $\begin{array}{c}\text { Male } 278-291 \\
\text { Female } 291-293\end{array}$ & $\begin{array}{c}\text { Male } 278-286 \\
\text { Female } 279- \\
294\end{array}$ & Male 287-322 & $325-385$ \\
\hline $\begin{array}{l}\text { Posterior end } \\
\text { of } A D\end{array}$ & Triangular & Triangular & Triangular & Rounded & Rounded & Triangular \\
\hline Cornea on OC & $\begin{array}{l}\text { Remnants } \\
\text { of cornea }\end{array}$ & Absent & Present & Present & Present & Present \\
\hline $\begin{array}{l}\text { Position of } \\
\text { ds } 1\end{array}$ & $\begin{array}{l}\text { Anterior part } \\
\text { on } \mathrm{AD}\end{array}$ & $\begin{array}{c}\text { About middle } \\
\text { on AD }\end{array}$ & $\begin{array}{c}\text { Posterior part of } \\
\text { AD }\end{array}$ & $\begin{array}{l}\text { About middle } \\
\text { of } \mathrm{AD}\end{array}$ & $\begin{array}{c}\text { About middle } \\
\text { of } \mathrm{AD}\end{array}$ & $\begin{array}{c}\text { Posterior part } \\
\text { of } \mathrm{AD}\end{array}$ \\
\hline $\begin{array}{l}\text { Position of } \\
\text { ds } 2\end{array}$ & $\mathrm{OC}$ & $\begin{array}{l}\text { Membranous } \\
\text { cuticle }\end{array}$ & $\mathrm{OC}$ & $\mathrm{OC}$ & $\mathrm{OC}$ & $\mathrm{OC}$ \\
\hline $\begin{array}{l}\text { Position of } \\
\text { ds } 3\end{array}$ & $\mathrm{OC}$ & $\mathrm{OC}$ & $\mathrm{PD}$ & $\mathrm{OC}$ & $\mathrm{OC}$ & $\mathrm{OC}$ \\
\hline Costae on PD & $\begin{array}{l}\text { Very faint line } \\
\text { like }\end{array}$ & Absent & $\begin{array}{c}\text { Present, two } \\
\text { porose panel wide }\end{array}$ & Absent & Present & Absent \\
\hline Panels on PD & $\begin{array}{c}\text { Reticulate } \\
\text { panels on PD }\end{array}$ & $\begin{array}{c}\text { Median portion } \\
\text { deliculately } \\
\text { reticulate }\end{array}$ & $\begin{array}{c}\text { Reticulate panels } \\
\text { on PD }\end{array}$ & $\begin{array}{l}\text { Smooth area } \\
\text { on PD }\end{array}$ & $\begin{array}{c}\text { Reticulate } \\
\text { panels on PD }\end{array}$ & $\begin{array}{c}\text { Reticulate } \\
\text { panels on PD }\end{array}$ \\
\hline $\begin{array}{l}\text { Wart on } \\
\text { membranous } \\
\text { cuticle on } \\
\text { idiosoma } \\
\text { dorsal }\end{array}$ & Present & Absent & Absent & Absent & Present & Absent \\
\hline $\begin{array}{l}\text { Setae on } \\
\text { basifemur III }\end{array}$ & 3 & 3 & 2 & 3 & 3 & 3 \\
\hline $\begin{array}{l}\text { Bipectinate } \\
\text { seta in tibiae I } \\
\text { to IV }\end{array}$ & $1-1-1-0$ & $1-1-1-1$ & $1-1-1-0$ & $1-1-1-0$ & $1-1-1-0$ & $1-1-1-?$ \\
\hline $\begin{array}{l}\text { Distance } \\
\text { between } \\
\text { anterior end } \\
\text { of GO and GA } \\
\text { in male }\end{array}$ & $\begin{array}{l}0.7 \text { of GO } \\
\text { length }\end{array}$ & $\begin{array}{l}\text { Slightly less } \\
\text { than GO length }\end{array}$ & 1.1 of GO length & $\begin{array}{l}0.7 \text { of GO } \\
\text { length }\end{array}$ & $\begin{array}{l}\text { Equal with } \\
\text { GO length }\end{array}$ & $\begin{array}{l}1.8 \text { of Go } \\
\text { length }\end{array}$ \\
\hline
\end{tabular}

Suctorian and Peritrich ciliate epibionts have been found on several halacarid mites (Chatterjee, Dovgal, Pešić, Zawal, 2018b). Bartsch (2015) reported suctorian ciliate Praethecacineta halacari (Schulz, 1933) on Acarothrix grandocularis from Singapore. 


\section{Acknowledgement}

Thanks are due to Dr. Martin V. Sorensen, Natural History Museum of Denmark, University of Copenhagen, Denmark for making the SEM photographs; to Dr Mandar Nanajkar, CSIR, National Institute of Oceanography, Dona Paula, Goa-403004, India and Mr. Souhardya Chatterjee for their help to arrange the figure plates.

\section{References}

Bartsch, I. (2004). Acarothrix ampliata (Arachnida: Acari: Halacaridae), a new halacarid mite from Florida, with notes on external genital acetabula. Species Diversity, 9, 259-267.

Bartsch, I. (1990). Acarothrix palustris gen. et spec. nov. (Halacaroidea, Acari), ein Bewohner der Salzwiesen Südchinas. Zoologischer Anzeiger, 224, 204-210.

Bartsch, I. (1997). Copidognathinae (Halacaridae, Acari) from northern Australia; description of four new species. In: J.R. Hanley, G. Caswell, D. Megirian, H.K. Larson (eds.), Proceedings of the Sixth International Biological Workshop (pp. 231-243). Museums \& Art Galleries of Northern Territory, Darwin.

Bartsch, I. (2006). Copidognathines (Acari: Halacaridae) in mangroves of Singapore. I. Description of three species. The Raffles Bulletin of Zoology, 54, 83-92.

Bartsch, I. (2015). Halacaridae (Acari) amongst the epiflora fauna on trunk, branches, roots and pneumatophores on the coast of Singapore: a survey. Raffles Bulletin of Zoology, 31 (supplement), 96-138.

Chatterjee, T., Dovgal, I., Pešić, V., Zawal, A. (2018b). A checklist of epibiont suctorian and peritrich ciliates on halacarid and hydrachnid mites (Acari: Halacaridae and Hydrachnidia). Zootaxa, 4457 (3), $415-430$.

Chatterjee, T., Guru, B.C. (2012). Sexual dimorphism in halacarid mites (Acari, Halacaridae): An updated overview. Acta Biologica, 19, 99-12.

Chatterjee, T., Guru, B.C., Sorensen, M.V. (2013). Report of Acarothrix palustris Bartsch (Acari: Halacaridae) from the Indian Ocean, Acta Biologica, 20, 17-26.

Chatterjee, T., Marshall, D.J., Guru, B.C., Ingole, B., Pešić, V. (2012). A new species of the genus Acarothrix (Acari, Halacaridae) from Brunei Darussalam and India. Cahiers De Biologie Marine, 53 (4), 541-546.

Chatterjee, T., Pfingstl, T., Pešić, V. (2018a). A checklist of marine littoral mites (Acari) associated with mangroves. Zootaxa, 4442 (2), 221-240.

Procheş, Ş. (2002). New species of Copidognathinae (Acari: Halacaridae) from southern Africa. Journal of Natural History, 36, 999-1007.

Procheş, Ş., Marshall, D.J., Ugrasen, K., Ramcharan, A. (2001). Mangrove pneumatophores arthropod assemblages. Journal of the Marine Biological Association, 81, 545-552.

Cite as: Chatterjee, T. (2019). Scanning electron microscopic observation of Acarothrix grandocularis (Acari, Halacaridae) and notes on the species of the genus Acarothrix. Acta Biologica, 26, 117-126. DOI: 10.18276/ab.2019.26-10. 